\title{
THE ROLE OF FAMILY IN PREVENTING SOCIAL CONFLICT IN SOCIETY FROM ISLAMIC PERSPECTIVES
}

\section{Rusli $^{1}$}

${ }^{1}$ Postgraduate Program, Institut Agama Islam Negeri Palu, Palu, rusli@iainpalu.ac.id

\begin{abstract}
This paper deals with the role of family in preventing social conflict and tensions within community. It is argued that family plays a significant role in establishing norms and rules in preventing social conflict and tension in the community. And in Islam, family is described as a school that children can learn moral values from their parents. The cultivation and strengthening of character in family can be carried out in various ways. First, providing halal food to the children since there is correlation between the food consumed and character; second, teaching moral values to the children so that they know what is good or not good in life; third, instilling good character values into children so that they become good generations in society. This character education by parents includes, first, education that provides knowledge about the importance of values that prevent conflict and violence in society; second, education that provides good examples, and third, education through continuous habituation.
\end{abstract}

Keywords: family, social conflict, character education, moral values

Abstrak. Artikel ini berkaitan dengan peran keluarga dalam mencegah konflik sosial dan ketegangan dalam masyarakat. Dikatakan bahwa keluarga memainkan peran penting dalam menetapkan norma dan aturan dalam mencegah konflik dan ketegangan sosial di masyarakat. Dan dalam Islam, keluarga digambarkan sebagai sekolah dimana anak-anak dapat belajar nilainilai moral dari orang tua mereka. Budidaya dan penguatan karakter dalam keluarga dapat dilakukan dengan berbagai cara. Pertama, memberikan makanan halal kepada anak-anak karena ada korelasi antara makanan yang dikonsumsi dan karakter; kedua, mengajarkan nilai-nilai moral kepada anak-anak sehingga mereka tahu apa yang baik atau tidak baik dalam hidup; ketiga, menanamkan nilai-nilai karakter yang baik ke dalam anak-anak sehingga mereka menjadi generasi yang baik di masyarakat. Pendidikan karakter ini oleh orang tua meliputi, pertama, pendidikan yang memberikan pengetahuan tentang pentingnya nilai-nilai yang mencegah konflik dan kekerasan dalam masyarakat; kedua, pendidikan yang memberikan contoh yang baik, dan ketiga, pendidikan melalui pembiasaan berkelanjutan. 
Keywords: keluarga, konflik sosial, pendidikan karakter, nilai moral

\section{Introduction}

Family is one of the fundamental pillars of society and it is also one of the most important elements in the community. Without family, there is no community. The damage to the family will greatly affect the harmony and stability of society. On the contrary, family harmony contributes greatly to the strength of a society. For this reason, it can be said that the family plays a significant role in either strengthening or weakening a society.

Conflict is a phenomenon that often arises in society, and even it is an inseparable part of the society. The differences that have existed in society either in culture, religion, ethnicity, ideology, or race, are undoubtedly socially potential for the emergence of conflict. Several conflicts that had occurred in Indonesia so far can prove this case. Many attempts and efforts were made to prevent this conflict from happening, spreading and escalating, and even various perspectives, approaches, ways and methods, are used to overcome the conflicts. There are some who argued that a comprehensive preventive strategy must first focus on the underlying political, social, economic, and environmental causes of conflict, while others argued that the strategy must include peace building, an activity that aims to resolve injustice in non-violent ways and to transform the cultural and structural conditions that generate deadly or destructive conflict. It resolves around developing constructive personal, group, and political relationships across ethnic, religious, class, national and racial boundaries. This process includes violence prevention, conflict management, resolution, or transformation. In Islamic history, this process was also run by the Prophet. ${ }^{1}$

However, there is one way that may need serious attention; that is, the prevention from an early time begins from the social institution that is called "family". As previously stated, family may be one of the most significant factors in strengthening harmony within society. Therefore, the question that may arise is how does the family play a role in preventing social conflict and tensions in society? This paper tried to answer this question using sociological approach.

\section{Previous Studies}

Studies on family have been conducted a lot using various perspectives and approaches. From educational perspective, for instance, there is one study

\footnotetext{
${ }^{1}$ Rusli Rusli, “The Role of Musalahah in Conflict Resolution: A Historical Perspective," Hunafa: Jurnal Studia Islamika 10, no. 2 (December 15, 2013): 203-220.
} 
conducted by O'Neal. ${ }^{2}$ In his study, he showed that showed that teaching problem-solving skills to students as a way to reduce and prevent conflict is one approach to prevention services. This article describes the functions of the consultation and education department and the community training specialist. In addition, the three levels of the conflict prevention program are described, and the results of the precession and post session questionnaire are discussed. The social worker, as a community training specialist, is in a position to propose solutions and collaborate in a school setting using this three-dimensional paradigm for training with students, faculty, and family.

Another study from psychological perspective, for instance, is carried out by Coco and Courtney. ${ }^{3}$ They come to conclusion that a family therapy approach, combining the conceptual frameworks of the Bowen model and Olson's Circumplex model, was used to restructure family relationships in order to prevent further runaway behavior of a 15-year-old Mexican-American female. A structured family interview was conducted to identify problems, a genogram was used to obtain the family's history, and therapy (family, individual, and mother-daughter) was provided to change the family system. The Family Satisfaction Scale was administered to evaluate the effectiveness of this therapeutic approach.

Furthermore, another study from the same perspective is conducted by Kumpfer and Alvarado. ${ }^{4}$ They argued that effective parenting is the most powerful way to reduce adolescent problem behaviors. Dissemination of research-based family interventions has been slow, with most practitioners still implementing ineffective programs. This article reviews 2 federal studies that involved national searches for effective family interventions targeting prebirth to adolescence: Preventing Substance Abuse Among Children and Adolescents: Family-Centered Approaches. Results identified 3 effective prevention approaches, 13 principles of effectiveness, and 35 programs. Recommendations include increased dissemination research on training and technical assistance systems, adoption with fidelity and quality, and gender-, age-, and culturally sensitive adaptations.

However, the study that focused on the role of family in preventing social conflict has not been carried out so far. Therefore, this study is oriented to deal with this issue.

\footnotetext{
${ }^{2}$ Gwenelle S. O’Neal, “Preventing Conflict: Encouraging Collaboration among Students, Faculty, and Family," Children \& Schools 15, no. 2 (1993): 83-89.

${ }^{3}$ E. Lane Coco and Linda J. Courtney, "A Family Sistems Approach for Preventing Adolescent Runaway Behaviour," Adolescence 33, no. 130 (1998): 485-496.

${ }^{4}$ Karol L. Kumpfer and Rose Alvarado, "Family-Strengthening Approaches for the Prevention of Youth Problem Behaviors," American Psychologist 58, no. 6-7 (2003): 457-465.
} 


\section{Theoretical Framework}

This paper used structural functionalism as a tool of analysis to understand the role of family in preventing social conflict. ${ }^{5}$ The major assumption of this theory is that the family performs several essential functions for society. It socializes children, it provides emotional and practical support for its members, it helps regulate sexual activity and sexual reproduction, and it provides its members with a social identity. In addition, sudden or farreaching changes in the family's structure or processes threaten its stability and weaken society.

The functional perspective emphasizes that social institutions perform several important functions to help preserve social stability and otherwise keep a society working. A functional understanding of the family thus stresses the ways in which the family as a social institution helps make society possible. As such, the family performs several important functions.

First, the family is the primary unit for socializing children. No society is possible without adequate socialization of its young. In most societies, the family is the major unit in which socialization happens. Parents, siblings, and, if the family is extended rather than nuclear, other relatives all help to socialize children from the time they are born. The socialization process involves an agent (a source of instruction), a learning process, a target (the individual being socialized), and an expected outcome. ${ }^{6}$ Socialization into the normative order begins with the family, where the child learns to function with the framework of a given society. ${ }^{7}$

Second, the family is ideally a major source of practical and emotional support for its members. ${ }^{8}$ It provides them food, clothing, shelter, and other essentials, and it also provides them love, comfort, help in times of emotional distress, and other types of intangible support that we all need. As a result, they become emotionally and psychologically mature. Rodin and Salovey ${ }^{9}$ revealed that family and marriage are the most important sources of social support. Family support is a form of interpersonal relationships that protect a person

${ }^{5}$ See Nancy Kingsbury and John Scanzoni, "Structural Functionalism," in Sourcebook of Family Theories and Methods: A Contextual Approach, ed. S.K. Boss, P., Doherty, W.J., LaRossa, R., Schumm, W.R., Steinmetz (New York: Springer, 2009), 195-217; See also Michael Ryan, "Structural Functionalism," in Encyclopedia of Social Theory, ed. George Ritzer (California: SAGE Publications Inc., 2012); See also T Parsons, The Social System (London: Routledge, 1951).

${ }^{6}$ John D. DeLamater and Andrew H. Michener, Social Psychology, 4th ed. (Fort Worht, TX: Harcourt Brace College Publisher, 1999), 50.

${ }^{7}$ Frederick Elkin and Gerald Handel, The Child and Society, 2nd ed. (New York: Random House, 1972), 5.

${ }^{8}$ See D. Russell and Tim B. Heaton Crane, ed., Handbook of Families and Poverty, 1st ed. (London and Los Angeles: SAGE Publications Inc., 2007), 378.

${ }^{9}$ Cited in Smet Bart, Psikilogi Kesehatan (Jakarta: PT. Gramedia Widiasarna Indonesia, 1994). 
from the effects of bad stress. ${ }^{10}$ It can be said that family support is very useful in controlling one's level of anxiety and can also reduce the pressures that exist in conflicts that happen in him. The support is in the form of encouragement, motivation, empathy, or assistance that can make other individuals feel more comfortable and secure. Support is obtained from families that consist of husbands, parents, or other close relatives. Family support can bring pleasure, security, satisfaction, comfort and make the person feel emotional support that will affect the welfare of the human soul. Family support is related to the formation of mental balance and psychological satisfaction.

Third, the family helps regulate sexual activity and sexual reproduction. All societies have norms governing with whom and how often a person should have sex. The family is the major unit for teaching these norms and the major unit through which sexual reproduction occurs. One reason for this is to ensure that infants have adequate emotional and practical care when they are born. The incest taboo that most societies have, which prohibits sex between certain relatives, helps to minimize conflict within the family if sex occurred among its members and to establish social ties among different families and thus among society as a whole.

Fourth, the family provides its members with a social identity. Children are born into their parents' social class, race and ethnicity, religion, and so forth. As we have seen in earlier chapters, social identity is important for our life chances. Some children have advantages throughout life because of the social identity they acquire from their parents, while others face many obstacles because the social class or race and ethnicity into which they are born are at the bottom of the social hierarchy.

\section{The Root of Social Conflict in Society: Sociological Analysis}

Since Indonesia entered the reform era, various events have occurred from the emergence of religious movements such as Salafi groups both in the real world and in cyberspace, ${ }^{11}$ the outbreak of terror movements in the name of religion, ${ }^{12}$ and many social events that have occurred in Indonesia which tend to be destructive, both in the form of tribal conflicts, class, religion and politics.

\footnotetext{
${ }^{10}$ Kaplan and Sadock, Sinopsis Psikiatri Ilmu Pengetahuan Perilaku Psikiatri Klinis, 7th ed. (Jakarta: Bina Aksara, 1998).

${ }^{11}$ R. Rusli, "Progressive Salafism in Online Fatwa," Al-Jami'ah (2014); Rusli, "Indonesian Salafism on Jihād and Suicide Bombings," Journal of Indonesian Islam (2014); Rusli Rusli, "Wahdah Islamiyyah Palu: On Contemporary Islamic Legal Issues In The Internet," Hunafa: Jurnal Studia Islamika (2017).

${ }^{12}$ Julie Chernov Hwang, "Terrorism in Perspective: An Assessment of 'jihad Project' Trends in Indonesia," Asia Pacific Issues 104 (2012): 1-12; Jessica Stern, Terror in the Name of God: Why Religious Militants Kill (New York: Harper Collins, 2003).
} 
The example includes social conflict that occurred in Ambon, ${ }^{13}$ Poso, ${ }^{14}$ Sampit, ${ }^{15}$ Sambas, ${ }^{16}$ and other areas in Indonesia. It seems that society is easily suspicious, and shows hatred and enmity towards others. Experts and researchers have their own individual reports on various factors that cause social conflict in Indonesian. Most of them said that the factors include cultural, social, economic, religious, political, and others.

Among the results of the study was a research report from the Research and Development Agency, Indonesian Ministry of Religion, which found that the root causes of social conflict in Indonesia are motivated by three things. (1) The crisis in various fields that occurred several years ago. In addition to creating a loss of trust of some people in the government apparatus, the bureaucracy and the military which over the years have shown an attitude that lacks the sympathy of some people, also raise a high level of mutual suspicion among various community groups; (2) As a result of the globalization of information, religious ideologies and views have also developed which increasingly creates exclusivity and sensitivity to group interests; (3) There are socio-economic and political gaps. This gap makes it easier for followers of the religion get involved in the stream of competition, opposition and even hostility between groups. ${ }^{17}$

However, in general, if explored more deeply about the root causes of conflicts that had occurred in Indonesia, it can be said that the root cause lies in the issue of character, namely the lack of ability to manage their emotions, so that they are easily provoked and moved to violence against people or other groups, whether in the name of religion, culture, or others. Whatever has the potential to trigger various conflicts, if the related parties have good character, then it will not lead to bloody conflicts. Based on that, character education becomes very important. The first character education takes place in the family, then the environment and school.

\section{The Significance of Family in Islam}

13 Debora Sanur Lindawaty, "Konflik Ambon: Kajian Terhadap Beberapa Akar Permasalahan Dan Solusinya," Politica 2, no. 2 (2011): 271-297; Jamin Safi, "Konflik Komunal: Maluku 1999-2000," ISTORIA: Jurnal Pendidikan dan Ilmu Sejarah 12, no. 2 (2017): 33-44.

${ }^{14}$ Igneus Alganih, "Konflik Poso (Kajian Historis Tahun 1998-2001)," Criksetra: Jurnal Pendidikan Sejarah 5, no. 2 (2016): 166-174.

${ }^{15}$ Ruslikan, "Konflik Dayak-Madura Di Kalimantan Tengah: Melacak Akar Masalah Dan Tawaran Solusi," Masyarakat, Kebudayaan dan Politik 14, no. 4 (2001): 1-12; Abdul Rachman Patji, “Tragedi Sampit 2001 Dan Imbasnya Ke Palangkaraya (Dari Konflik Ke (Re)Konstruksi)," Jurnal Masyarakat dan Budaya 5, no. 2 (2003): 14-34.

${ }^{16}$ Kirsten E. Schulze, "The 'Ethnic' in Indonesia's Communal Conflicts: Violence in Ambon, Poso, and Sambas,” Ethnic and Racial Studies 40, no. 12 (2017): 2096-2114.

${ }^{17}$ M. Atho Mudzhar, Kebijakan Negara Dan Pembangunan Lembaga Pemimpin Agama Dalam Rangka Keharmonisan Hubungan Antar Umat Beragama (Jakarta: Puslitbang Depag, 2004), 14-15. 
What is a family? In the most basic definition, a group of people who share a legal bond or a blood bond is a family. A legal bond means "families are legally bound through marriages, adoptions, and guardianships, including the rights, duties, and obligations of those legal contracts. Legal bonds can be changed, expanded, or dissolved to change the composition of a family", while blood bond refers to "individuals who are directly related through a common ancestor are part of a family. This includes both close and distant relatives such as siblings, parents, grandparents, aunts, uncles, nieces, nephews, and cousins. Researching a family tree or genealogical records can reveal familial blood bonds." 18

Family in general consists of father, mother, and children. The father is the main axis and becomes a reference in forming a family, and he is obliged to provide a living, protection and education to his children. In Islam, this kind of protection and financial support is included in the category of nafaqah, which is obligatory, which if it is not carried out properly, then according to Islam, the person will have sin. ${ }^{19}$

Mother who is a partner of the father has a very vital role in shaping the character and mental health of children. Even in a wise sentence or poem it says, "Mother is like a school. If it is well prepared, it will prepare generations of fragrant scents" (al-umm madrasah idhā a'dadtahā a'dadta sha'b țayyib al$\left.a^{\prime} r \bar{a} q\right) .{ }^{20}$ Even, mother has multi role in the family, one of them are the role of the educator to their children, which guide, educate and fostering to be noble children, righteous to their parents, useful for nation. To play the role as Islamic educator in the family, a mother needs to have various knowledge that is not only obtained in formal education, but also through informal education and non-formal education. ${ }^{21}$

Azizah proposes a way to provide knowledge to mother as a woman. One of them is through the Quran Recitation Forum. The activities of Quran recitation forum as one of a form of non-formal education gave various science to women. Quran recitation forum for women is one of the process of education to apply for life. It is as one of the efforts in the development of the role of women as Islamic educator who in the family, where it was done to increase knowledge, understanding and a really immersive experience for women, so

18 Lovetoknow, "Meaning of Family," accessed February 24, 2020, https://family.lovetoknow.com/about-family-values/meaning-family.

${ }^{19}$ M. Afzal Wani, "Maintenance of Women and Children Under Muslim Law:Legislative Trends in Muslim Countries," Journal of the Indian Law Institute 45, no. 3/4 (2003): 409-428.

${ }^{20}$ This verse is from one of the poems of the great poet Hafez Ibrahim, and this poem is called the poem of science and morals (qașidah al-ilm wa al-akhlāq).

${ }^{21}$ Zahratul Azizah, "The Development of the Role of Women as Islamic Educator in Family Through Activity of the Quran Recitation Forum," Advances in Social Science, Education and Humanities Research, 293, no. Nfeic 2018 (2019): 159. 
that by this activity for educators to woman expect for her child can apply this knowledge in the family for developing Islamic sticks. ${ }^{22}$

Each individual in the family is charged by God, according to Islam, with the task of protecting each other and guarding them from the touch of hellfire and the actions that lead to it. The Quran said, "O you who have believed, protect yourselves and your families from a Fire whose fuel is people and stones, over which are [appointed] angels, harsh and severe; they do not disobey Allah in what He commands them but do what they are commanded" (QS al-Tahrīm 6). This means that an individual must fortify himself and his family with good character so as not to fall into hell. There is a strong relationship between hell and bad character.

Islam views the family as the first brick to build a structure of community, and as the first school of faith which is expected to produce good generations on earth. If the family foundation is strong, has a good understanding in religion, and good character of its members, then society will become strong, and it manifests a sense of security in it. In contrary, if family ties disintegrate and damage is poisoning its members, then the bad impact is seen on society, namely disorder, chaos, and social fragility, so security is not obtained.

Islam also regards the family as a pillar of society and at the same time a pillar of the state, even also a pillar of religion. On this basis, Islam pays very serious attention to family matters. Among the indicators, in the Quran, it is not only found as a family term with various terms such as ahl, dhū al-qurbā, alaqārib, and others, but also there are a number of Quranic verses that regulate family matters. The Quran regulates marital matters, guardianship, financial support (nafaqah), childcare (hadāanah), and so on.

Therefore, family is something that is very sacred and important. Because of the importance of this family, before building a household, Islam teaches premarital education. One form of education is the procedure for choosing a partner. In a narration of the hadith of the Prophet Muhammad, it is stated that there are several considerations when a person marries a woman, namely beauty, ancestry, wealth, and religion. The first three are temporary, while the last is eternal. So, the Prophet emphasized to choose a partner based on religious considerations. If this is done, then domestic life can be harmonious and work well.

It is interesting to note why religion is emphasized. The reason is that religion is an integrative force. Its primary function is to preserve and solidify society. It functions to reinforce the collective unity or social solidarity of a group. Durkheim, ${ }^{23}$ for instance, said that religion encourages shared values, interactions, strong social ties that protect individuals from social alienation. In the family, religion has the same influence. Families who practice their

${ }^{22}$ Ibid., 161.

${ }^{23}$ Emile Durkheim, Suicide: A Study in Sociology (New York: Free Press, 1951). 
religion well will be more cohesive. In their research, Stinnet and DeFrain found that spiritual wellness is one of the six most cited qualities that contribute to family well-being. ${ }^{24}$ Curran also reports that religion ranks 10th out of 56 characteristics of "healthy families". ${ }^{25}$ This research implies that religious experiences in the family stimulate family relationships.

From these studies, it can be concluded that a family built from religious values will lead to a harmonious family. A harmonious family becomes the foundation for a civilized and moral society, because a harmonious family gives birth to generations who are pillars of society, not a generation that always causes problems or conflicts in society.

\section{The Role of Family in Preventing Social Conflict}

It is believed that a family plays an important role in life because every human being or Muslim must depart from a family. So it can be concluded that the family is a place where the foundation of religious values is established by both parents and other family members to a child.

It can be argued that conflicts occur not only because of differences in religion, ethnic groups, and economic inequality, but also the problem of bad character found in the perpetrators. If a person's character is not good, then it can cause various problems in life. Various cases and facts prove this case. For this reason, character education becomes very important and urgent.

What is character education? In simple words, character education is education that nurtures and promotes the ethical, intellectual, social and emotional development of individuals. It is a continuous learning process that enables young people and adults to become moral, caring, critical, responsible individuals. Character education represents a relationship between knowledge, values and skills necessary for success in life. By knowledge, we refer to two kinds of knowledge: a) general knowledge; that is, knowledge that encompasses a wide subject range and $b$ ) specialized knowledge obtained via extensive reading and training in a particular area or field of studies. Values, on the other hand, are the beliefs and moral codes of a person or a society about what is good and bad which tend to influence attitudes and behaviors. Lastly, skills - or better life skills - are the abilities that individuals possess acquired via teaching, training, or direct experience that enable them to cope with the demands and challenges of everyday life.

The family is the first school expected to carry out these functions and tasks. Then, what is the role that can be played by the family to prevent conflicts

\footnotetext{
${ }^{24}$ Nick Stinnett \& John DeFrain, Secrets of Strong Families (Boston: Little, Brown, and Company, 1985).

${ }^{25}$ Dolores Curran, Traits of a Healthy Family (Minneapolis: Winston Press, 1983).
} 
and tensions in the community? At least, the roles can be either in the form of preventive or curative roles. However, this paper does not deal with the curative roles that family can play in order to solve this issue, but it focused more on preventive role of family in preventing social conflict within society. For this role to be effective there is one important prerequisite that must be fulfilled; that is, the family must not have problems or are done with their problems. This is indicated by the existence of good communication between each family member, and family harmony as well.

The most important role that family plays is preventive role. In this role, there are several tasks and duties that the family-father and mother-must carry out.

First, the most important task of family is to provide and feed the children halal food, since in Islam, the Quran obliged the Muslims to eat halal food. God very clearly mentioned in the Quran what is prohibited from the food and meat, such as al-Baqarah 173, al-Nisā' 3, al-An'ām 145 and al-Nahl 115. From these verses you can know what is Halal (lawful) meat and what is haram (prohibited). ... And this is also supported by the Hadith that makes a strong correlation between the haram food and bad behavior that leads to the hell fire. The Prophet said, "Every flesh nourished by Haram, the Hell-Fire deserves it more than any other place" (kull lahm nabata min al-harām fa al-nār awlā bihi). ${ }^{26}$ This means that the food eaten will move the person to do bad deeds that only lead to the hell. Therefore, Islam pays a serious attention to the issue of food, and instructs only to eat halal food, both in its substance, its process, and its method of acquisition.

Second, the father and mother must teach their children or instill knowledge to them about what should be done in this life. Related to the problem of conflict and violence, children must be taught about the negative impacts that can be generated by destructive social conflict, so as far as possible it should be avoided. Children must also be taught about the importance of respecting differences, because one of the causes of conflict and social tension is the differences that exist in society. The Quran itself recognizes that, " $O$ mankind, indeed We have created you from male and female and made you peoples and tribes that you may know one another. Indeed, the most noble of you in the sight of Allah is the most righteous of you. Indeed, Allah is Knowing and Acquainted." (QS Al-Hujurāt 13). In another verse, it is stated that, “...Had Allah willed, He would have made you one nation [united in religion], but [He intended] to test you in what He has given you; so race to [all that is] good. To

${ }^{26}$ See Abdullah ibn 'Adi Al-Jurjani, Al-Kamil Fi Du'afa Al-Rijal, Vol. 5, ed. Adil Ahmad Abd Al-Mawjud (Beirut: Dar al-Kutub al-'Ilmiyyah, 1984); .See also Muhammad ibn Isa Al-Turmudhi, Al-Jami' Al-Kabir, ed. Bashar Awwad Ma'ruf, 1st ed. (Beirut: Dar al-Gharb al-Islami, 1996) Haidth No. 614 . 
Allah is your return all together, and He will [then] inform you concerning that over which you used to differ" (QS. Al-Mā'idah 48). In addition, they are taught about the importance of tolerance and being gentle with humans and humanity regardless of what ethnic group, cultural group, or religion is.

Third, the father and mother must instill moral values or teachings or characters in the child and familiarize them in everyday life both in the family or community. There are many character qualities that must be developed in the family environment; however, there are nine character values which are universal and noble. According to Ratna Megawangi, ${ }^{27}$ these values include: (1) love of God and all His creation; (2) responsibility, discipline and independence; (3) honesty; (4) respect and courtesy; (5) love, care and cooperation; (6) confident, creative, hard work, and never give up; (7) justice and leadership; (8) kind and humble; (9) tolerance, love for peace and unity.

However, among those values that may be urgently applied in relation to conflict prevention are respect and tolerance. Respect includes respect for ourselves, others, and all forms of life and the environment. Respect for ourselves requires that we treat what is in our lives as humans who have value naturally. So, self-destruction both in the form of drug and alcohol abuse is something that cannot be justified. Respect for others requires us to treat all people, even those we hate, as human beings who have high values and have the same rights as us as individuals. ${ }^{28}$

Tolerance is a reflection of respect. In language, tolerance means "willingness to accept behavior and beliefs that are different from your own, although you might not agree with or approve of them." ${ }^{29}$ In Arabic, tolerance is called al-tasāmuh and al-samāhah. The meaning revolves around being kind and giving to others generously and with noble intentions; easiness; obedience and submission; spaciousness. In Islam, tolerance is a religious obligation (faridah diniyyah). Tolerance is not a gift from the strong to the weak, but an essential value taught by Islam and an inherent characteristic of Islamic teachings. In fact, in Islam, tolerance is a necessity of life because we live in diversity, in which harmonious conditions in society can be achieved if each of us is tolerant and respectful of differences.

The method of instilling these nine values that are seen as pillars of character, is carried out explicitly and systematically, namely by knowing the good, reasoning the good, feeling the good, and acting the good. If this can be done well, it can successfully build children's character. By knowing the good, children are accustomed to thinking that only the good ones. Reasoning the

\footnotetext{
${ }^{27}$ Ratna Megawangi, Pengembangan Program Pendidikan Karakter Di Sekolah; Pengalaman Sekolah Karakter (Jakarta, 2010).

${ }^{28}$ Thomas Lickona, Educating for Character: How Our Schools Can Teach Respect and Responsibility (New York: Batam Books, 1991).

${ }_{29}$ Cambridge Dictionary, “Tolerance," accessed February 23, 2020, https://dictionary.cambridge.org/dictionary/english/tolerance.
} 
good also needs to be done so that children know why they have to do good. For example, why do children have to be honest, what are the consequences if the child is honest, and so on. Therefore, the child not only memorizes the good but also knows the reason. And also, with feeling the good, we build children's feelings of kindness. Children are expected to love kindness. Then, in acting the good, children practice kindness. If children are accustomed to knowing, reasoning, feeling, and acting the good over time the character will be formed.

This step is recommended by Thomas Lickona. ${ }^{30}$ In his book, Lickona emphasizes the importance of three components of good character, namely moral knowing, moral feelings and moral actions. This is necessary so that children are able to understand, feel and do at the same time good values. Moral knowing is an important thing to teach, consisting of six things, namely: moral awareness, knowing moral values, perspective taking, moral reasoning, decision making and self-knowledge.

Moral feeling is another aspect that must be instilled in children. This is a source of energy from the human self to act in accordance with moral principles. There are six aspects of emotions that must be able to be felt by someone to become a human of character, namely conscience, self-esteem, empathy (feeling the suffering of others), loving the good, self-control, and humility. One way to grow moral feeling is by raising children's awareness of the importance of commitment to moral values. For example, to instill a child's love for honesty by not cheating, parents must be able to foster guilt, shame and empathy for the cheating. This love (moral feeling) will be the most effective internal control, in addition to external control in the form of parental supervision of children's behavior in daily life

Moral action is how to make moral knowledge can be translated into concrete actions. This moral action is an outcome of two other components of character. To understand what drives a person to act morally, three other aspects of character must be seen, namely competence, will and habit.

In short, character education instills good habits to the children so they can understand, reason, feel, and do the good. However, in the implementation of character education, according to Lickona, it needs to involve the cooperation of schools and families. He explained that parent's involvement was the main indicator of school success. When schools and families work together to improve children's morale, character education will be achieved.

\section{Conclusion}

From the above explanation on the role of the family in preventing conflicts in society, it can be concluded that in order to prevent social conflict within community, it can be carried out through three following steps: the first

${ }^{30}$ Lickona, Educating for Character : How Our Schools Can Teach Respect and Responsibility. 
and the most important thing is providing them halal food, because haram food can lead to bad character and behavior; second, teaching and transferring knowledge related to moral conducts and its consequences; third, instilling good character values into children so that they become good generations in the community. Character education by parents includes education by providing knowledge about the importance of values that prevent conflict and violence in society, education by providing examples, and education through habituation. Or, in Lickona's words, knowing the good, reasoning the good, feeling the good, and acting the good.

\section{References}

Al-Jurjani, Abdullah ibn 'Adi. Al-Kamil Fi Du'afa Al-Rijal, Vol. 5. Edited by Adil Ahmad Abd Al-Mawjud. Beirut: Dar al-Kutub al-'Ilmiyyah, 1984.

Alganih, Igneus. "Konflik Poso (Kajian Historis Tahun 1998-2001)." Criksetra: Jurnal Pendidikan Sejarah 5, no. 2 (2016): 166-174.

Azizah, Zahratul. "The Development of the Role of Women as Islamic Educator in Family Through Activity of the Quran Recitation Forum." Advances in Social Science, Education and Humanities Research, 293, no. Nfeic 2018 (2019): 159-162.

Bart, Smet. Psikilogi Kesehatan. Jakarta: PT. Gramedia Widiasarna Indonesia, 1994.

Courtney, E. Lane Coco and Linda J. "A Family Sistems Approach for Preventing Adolescent Runaway Behaviour.” Adolescence 33, no. 130 (1998): 485-496.

Crane, D. Russell and Tim B. Heaton, ed. Handbook of Families and Poverty. 1st ed. London and Los Angeles: SAGE Publications Inc., 2007.

Curran, Dolores. Traits of a Healthy Family. Minneapolis: Winston Press, 1983.

Dictionary, Cambridge. "Tolerance." Accessed February 23, 2020. https://dictionary.cambridge.org/dictionary/english/tolerance.

Durkheim, Emile. Suicide: A Study in Sociology. New York: Free Press, 1951.

Gwenelle S. O’Neal. “Preventing Conflict: Encouraging Collaboration among Students, Faculty, and Family." Children \& Schools 15, no. 2 (1993): 83-89.

Handel, Frederick Elkin and Gerald. The Child and Society. 2nd ed. New York: Random House, 1972.

Hwang, Julie Chernov. "Terrorism in Perspective: An Assessment of "jihad Project' Trends in Indonesia.” Asia Pacific Issues 104 (2012): 1-12.

Kumpfer, Karol L., and Rose Alvarado. "Family-Strengthening Approaches for 
the Prevention of Youth Problem Behaviors." American Psychologist 58, no. 6-7 (2003): 457-465.

Lickona, Thomas. Educating for Character: How Our Schools Can Teach Respect and Responsibility. New York: Batam Books, 1991.

Lindawaty, Debora Sanur. "Konflik Ambon: Kajian Terhadap Beberapa Akar Permasalahan Dan Solusinya." Politica 2, no. 2 (2011): 271-297.

Lovetoknow. "Meaning of Family." Accessed February 24, 2020. https://family.lovetoknow.com/about-family-values/meaning-family.

Megawangi, Ratna. Pengembangan Program Pendidikan Karakter Di Sekolah; Pengalaman Sekolah Karakter. Jakarta, 2010.

Michener, John D. DeLamater and Andrew H. Social Psychology. 4th ed. Fort Worht, TX: Harcourt Brace College Publisher, 1999.

Mudzhar, M. Atho. Kebijakan Negara Dan Pembangunan Lembaga Pemimpin Agama Dalam Rangka Keharmonisan Hubungan Antar Umat Beragama. Jakarta: Puslitbang Depag, 2004.

Muhammad ibn Isa Al-Turmudhi. Al-Jami' Al-Kabir. Edited by Bashar Awwad Ma'ruf. 1st ed. Beirut: Dar al-Gharb al-Islami, 1996.

Nancy Kingsbury and John Scanzoni. "Structural Functionalism." In Sourcebook of Family Theories and Methods: A Contextual Approach, edited by S.K. Boss, P., Doherty, W.J., LaRossa, R., Schumm, W.R., Steinmetz, 195-217. New York: Springer, 2009.

Nick Stinnett \& John DeFrain. Secrets of Strong Families. Boston: Little, Brown, and Company, 1985.

Parsons, T. The Social System. London: Routledge, 1951.

Patji, Abdul Rachman. "Tragedi Sampit 2001 Dan Imbasnya Ke Palangkaraya (Dari Konflik Ke (Re)Konstruksi).” Jurnal Masyarakat dan Budaya 5, no. 2 (2003): 14-34.

Rusli. "Indonesian Salafism on Jihād and Suicide Bombings." Journal of Indonesian Islam (2014).

Rusli, R. "Progressive Salafism in Online Fatwa." Al-Jami'ah (2014).

Rusli, Rusli. "The Role of Musalahah in Conflict Resolution: A Historical Perspective." Hunafa: Jurnal Studia Islamika 10, no. 2 (December 15, 2013): 203-220.

--—. "Wahdah Islamiyyah Palu: On Contemporary Islamic Legal Issues In The Internet." Hunafa: Jurnal Studia Islamika (2017).

Ruslikan. “Konflik Dayak-Madura Di Kalimantan Tengah: Melacak Akar Masalah 
Dan Tawaran Solusi." Masyarakat, Kebudayaan dan Politik 14, no. 4 (2001): $1-12$.

Ryan, Michael. "Structural Functionalism." In Encyclopedia of Social Theory, edited by George Ritzer. California: SAGE Publications Inc., 2012.

Sadock, Kaplan and. Sinopsis Psikiatri Ilmu Pengetahuan Perilaku Psikiatri Klinis. 7th ed. Jakarta: Bina Aksara, 1998.

Safi, Jamin. “Konflik Komunal: Maluku 1999-2000." ISTORIA: Jurnal Pendidikan dan Ilmu Sejarah 12, no. 2 (2017): 33-44.

Schulze, Kirsten E. “The 'Ethnic' in Indonesia's Communal Conflicts: Violence in Ambon, Poso, and Sambas." Ethnic and Racial Studies 40, no. 12 (2017): 20962114.

Stern, Jessica. Terror in the Name of God: Why Religious Militants Kill. New York: Harper Collins, 2003.

Wani, M. Afzal. "Maintenance of Women and Children Under Muslim Law:Legislative Trends in Muslim Countries." Journal of the Indian Law Institute 45, no. 3/4 (2003): 409-428. 